\title{
16 \\ The regulatory state and beyond
}

\section{Colin Scott}

In John Braithwaite's remarkable set of contributions to ideas about and the practice of regulation over four decades, the state is one of the central organising concepts. This is true for much thinking about regulation more generally, but for a variety of reasons. In Braithwaite's case, the focus on the state may lie with his original interests as a criminologist, where there is a strong consensus that the responsibility for regulating criminal behaviour not only lies with the state, but also provides a core rationale for the existence of the state as monopolist over legitimate use of coercive power. Just as that consensus has broken down with the privatisation of some aspects of prisons and policing systems in various countries, so the agreement around the centrality of the state in regulation has been challenged. In this chapter, I argue that while some, including myself, have seen in Braithwaite's early and highly significant research on the role of the state in regulation a tendency to neglect the wider community and market context, in fact, the seeds of a more broadly based analysis of regulatory capitalism may be found throughout Braithwaite's oeuvre. Policy and scholarly communities were less receptive to understanding the key role of community and market actors set out from an early stage in Braithwaite's work and more fully developed in his later work. In this chapter, I attempt to locate Braithwaite's major contributions to the theory and practice of the regulatory state and the broader concept of regulatory capitalism within the wider context of contemporary thinking about regulatory governance. 


\section{Introduction}

I first encountered the scholarship of John Braithwaite when I read his article on enforced self-regulation (see Braithwaite 1982). The significance of this article was that it recognised the significant role of businesses in contributing to regulatory success while at the same time according to the state a central role in setting norms, monitoring and enforcement. That article set the stage for the later collaboration with Ian Ayres, Responsive Regulation (1992), which set out to 'transcend the deregulation debate' by showing the scope for finding common objectives and shared instruments between state, business and civil society in the development and implementation of regulation. John Braithwaite's scholarship, in common with professional life more generally, has constantly sought to take advantage of ways of working that prioritise the potential for collaboration and dialogue over other modes, which emphasise rivalry or coercion. This is reflected in his commitment to republican thinking about the state and civil society actors (Braithwaite 1997: 309) and his claim that 'most regulation can be about collaborative capacity-building' (Braithwaite 2011: 475).

In my own earlier readings of Braithwaite's scholarship, and of Responsive Regulation in particular, I have been critical of the central emphasis he places on the state (Scott 2004). However, in this chapter, I substantially revise this critique, as I think my earlier analysis was a misreading. While there is no doubt that Responsive Regulation has been most influential for what it has to say about the role and modes of operation of the state in regulatory governance, I suggest this has been because of a neglect of other important aspects of the work that have taken rather longer to take root in both scholarly and practice communities.

In particular, we find in Braithwaite's work, from the earliest days, a concern to identify capacity across state, business and civil society sectors, and to work out how shared capacity can be utilised in developing effective ordering. This more nuanced view of the role of the state in collaborative or network modes of governance is seen strongly in Braithwaite's more recent work on regulatory capitalism (Braithwaite 2008) and elsewhere. In this chapter, I aim to offer an evaluation of how Braithwaite's scholarship emphasises both the centrality of and the limits to the role of the state in regulatory governance. 


\section{Responsive enforcement and design in the regulatory state}

\section{The regulatory state}

The core idea of the regulatory state is that there is a distinctive mode of governance oriented towards the promulgation of rules that engages more or less systematic oversight of compliance with those rules by public agencies operating at arm's length from those they are overseeing (Levi-Faur 2013; Loughlin and Scott 1997; Majone 1994b). We might think of independent regulatory agencies' oversight of businesses as offering the core case of regulatory state governance (Selznick 1985). However, it is clear that the shift towards arm's-length oversight of compliance with rules as a governance mode extends well beyond independent regulators of business, and takes in also the separation and oversight of delivery functions within the public sector (Majone 1994a). To take the example of the utilities and network industries, such as communications, the regulatory mode of governance has been reflected in the corporatisation of telecommunications and postal services, which at one time were operated by government ministries and are now subject to regulatory oversight, whether the services are now offered by private companies, as is overwhelmingly the case with telecommunications, or by public bodies, as occurs in many countries in respect of postal services (Thatcher 2007). The communications sector actors have in common a trend towards oversight by reference to rules, displacing discretion, whether the rules and oversight are coming from ministries or agencies. Furthermore, the deployment of regulatory state mechanisms is not restricted to economic sectors, but also includes the redistributive functions of the state (Levi-Faur 2013, 2014; Mabbett 2011).

Arguably, the United States was a well-developed regulatory state by the 1930s, when the 'New Deal' agencies, such as the Federal Communications Commission, were introduced to subject a wide range of business activities to independent arm's-length oversight by reference to rules (Schultz and Doern 1998; Moran 2003). The terminology of the regulatory state was used extensively in comparisons of the administrative arrangements of the United States with those of countries which chose different models (Levi-Faur 2013). European attempts to address similar problems - of making utility services available and affordable as widely as possible — adopted public provision models, with a high degree 
of discretion, which came to be characterised as aspects of welfare state governance (Esping-Andersen 1990). Giandomenico Majone identified a trend towards convergence between Europe and the United States over regulatory state governance in the 1980s. This trend emerged both from a tendency towards prioritising regulatory governance modes in European Union (EU) policymaking (the EU institutions lacking the cash and the organisational capacity for substantial direct provision) and from the take-up of neoliberal policymaking (which tends to favour regulatory over welfare state modes of governance as representing a less intrusive and smaller state) in the United Kingdom and, progressively, in other European states from the 1980s (Majone 1994b). Significantly, the regulatory governance mode - often thought to focus on the exercise of public law power-places a significant emphasis on contractual instruments such as licences and bilateral contracts to set, monitor and enforce regulatory norms, both by governments and by others, on organisations that encompass state, market and community actors (Collins 1999; Scott 2002).

Braithwaite's own take on the development of the regulatory state starts with the nineteenth century and the idea of the state as a nightwatchman, providing the rules and enforcement through the courts to guarantee property rights and the enforcement of contracts sufficient to underpin the growth of enterprise (Braithwaite 2000). For Braithwaite, the Great Depression of the 1930s led to disenchantment with markets as the chief mode for organising and delivering services, and growth in the ambitions and capacity of the state both in direct provision of services and in its use of command capacity - the former perhaps more in European states and the latter perhaps more in North America (Braithwaite 2008: 15-16). The Keynesian welfare state, on both sides of the Atlantic, evidenced a belief that the state could deliver sufficient ordering generally and, for Braithwaite the criminologist, policing for society in particular. Braithwaite saw his home discipline of criminology as being closely linked to the rise of the welfare state and as coming under significant challenge from ideological and governance changes since the 1980s (Braithwaite 2000). A key change associated with the neoliberal reforms of the new regulatory state has been the privatisation of key elements of public service delivery and the establishment of new regulatory mechanisms to oversee them. This pattern ranges between network service providersfor example, in energy and communications (Prosser 1997)-and core elements of the criminal justice system including prisons (Harding 1997), security and policing (Crawford 2006; Loader 2000; White 2014). 
The separation of policymaking from operations across a wide range of public service activities, with privatisation of some and hiving off to separate public agencies of others, is a key element in establishing more formal and rule-based oversight relationships than were typical in welfare state arrangements. The nature of the fragmentation that accompanies the creation of arm's-length agencies for both delivery and regulation in rule-based governance regimes is demonstrated in the simplified model of the UK experience in the 1990s in Figure 16.1. What we see is not simply a shift from legislative discretion to the setting down of goals and expectations in rules, licences and contracts, but also the diffusion of responsibility for activities that had previously been managed directly by government ministries to executive agencies, linked to departments, to companies (some of them privatised) and to non-governmental organisations (NGOs). We see also, frequently, the recasting of the citizen as consumer (Barron and Scott 1992).

Welfare State

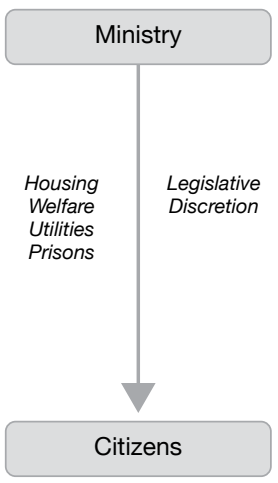

Regulatory State

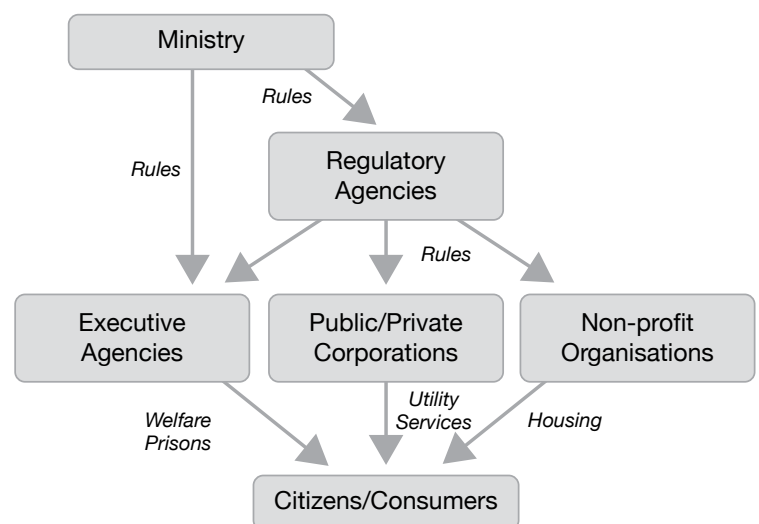

Figure 16.1 Simplified model of the United Kingdom's shift from welfare state to regulatory state

Source: Author's research.

Braithwaite's 'new regulatory state' is marked by its deployment of responsive techniques, which place greater emphasis on the steering of private and self-regulatory capacity over the aspiration to direct command and control (Braithwaite 2000: 224-5). Thus, the new regulatory state combines state oversight with marketisation of service provision and, in the responsive model, considerable responsibility for businesses to cooperate with state oversight. Thus, when considering the role of the state in regulation, there is a focus on the variety of modes 
of engagement with businesses and others, and how they may deliver on public interest objectives. This aspect is considered in the next two subsections of the chapter. However, it is clear that Braithwaite's focus has always been broader, and, reflecting on this, the following section takes us beyond the core focus on the state to consider more fully the roles of the widest range of actors within contemporary regulatory capitalism.

\section{Enforcement practices}

Braithwaite's research has been central to enhancing the range and quality of techniques available within the regulatory state. His 1986 study, with Peter Grabosky, of the enforcement practices of a wide range of Australian regulators was seminal in offering a systematic and empirically informed analysis of how regulators enforce the rules. A core theme of the study was captured in the book title, Of Manners Gentle (Grabosky and Braithwaite 1986). Grabosky and Braithwaite provided systematic evidence for observations made by others in more limited contexts (Cranston 1979) that enforcement agencies tend to rely to a large degree on education, advice and persuasion to secure compliance with regulatory rules, reserving formal and more stringent sanctions to egregious and persistent breaches. They gave empirical weight also to Donald Black's observation that the stringency of enforcement is shaped not only by instrumental considerations, but also by cultural factors, such as the degree of shared social history and engagement between enforcer and enforcee (expressed and measured in terms of 'relational distance') (Black 1976; Grabosky and Braithwaite 1986; Hood et al. 1999). There have been numerous attempts to reduce relational distance through such measures as rotating inspectors so that they do not get to know regulatees too well through regular visits and the appointment of outsiders, with no previous history with regulated firms or relevant social networks, to key regulatory roles.

Braithwaite further theorised these empirical observations in his collaboration with Ian Ayres, combining his research data with Ayres's game theoretical analysis to construct an enforcement pyramid that demonstrated the dependence of low-level persuasion on the capacity to escalate up the pyramid towards more stringent sanctions (Ayres and Braithwaite 1992). In game theoretic terms, the theory of responsive regulation suggested that regulators should start at the base of the pyramid with education and advice and escalate where there was noncompliance, 
but should be contingently forgiving and move back down the pyramid where regulatees fell into line (Ayres and Braithwaite 1992: 62-3). Such practices were advocated on the basis that the perception of fairness and responsiveness would build commitment among regulatees, while at the same time ensuring that regulators escalated sanctions where necessary. Such high-level sanctions might go as far as removing regulatees from the market through licence revocation, where they lacked either the will or the capacity to comply.

The concept of the enforcement pyramid takes as a starting point the presumption that regulators have a range of sanctions available to them. However, a key observation is that the 'sanctions' at the base of the pyramid are frequently not referred to in legislation or even conceived of as formal sanctions at all. It is only as we escalate up the pyramid that we invoke the formal sanctions. From this observation we may glean that regulators have a good deal of discretion in the deployment of their powers, which they use to construct their enforcement practices. This is true to the extent that regulators that lack formal enforcement powers may, nonetheless, be able to construct a form of enforcement pyramid. UK research that reads across the core literature on the regulation of businesses to examine the regulation of public sector bodies has demonstrated this potential, observing that organisations as diverse as the prisons inspectorate, the ombudsman and the National Audit Office lacked formal powers to apply sanctions to public bodies they found to be in breach of the rules. Nevertheless, they engaged in education and advice, sometimes offered warnings and then created a further level of sanction by drawing in the capacity of the media to name and shame those they found in breach (Hood et al. 1999). Others have noted that naming and shaming are, for some, more punitive than a fine (Baldwin and Black 2008: 86). In this instance, publicity was the top-level sanction, which is not the same as being able to fine or revoke a licence, but nevertheless is an action with considerable capacity to change behaviour in those agencies for whom the risk of adverse publicity was a significant deterrent. We may additionally note that the publicity sanction is dependent on the capacity of others (in this case, privately owned media organisations).

The example of the regulator that can build an enforcement pyramid from few materials, in terms of formal sanctions, should not be taken as a model. Rather, it is an example of necessity being the parent of imperfect invention. There can be no doubt that, other things being 
equal, a regulator with the capacity to escalate to more stringent sanctions will be better able to 'speak softly', because, in the quotation attributed to Theodore Roosevelt, they 'carry a big stick'. However, the nature of the big stick and its relationship to the gentle talking are important. A regulatory regime in which the formal enforcement powers contain only the most draconian measures, such as licence revocation and nothing else, will struggle to establish a credible enforcement pyramid. This is because draconian measures can only be used for the most persistent, wilful or egregious breaches. Most breaches do not fall into this category and, accordingly, the threat of formal sanctions will not be credible if the sanctions larder is bare of all but the most stringent sanctions. The pyramid with a large gap between the warnings level and the next level is a 'broken pyramid' and possibly not much better than the pyramid built by the regulator with no formal sanctions, and is, arguably, even worse (Scott 2010).

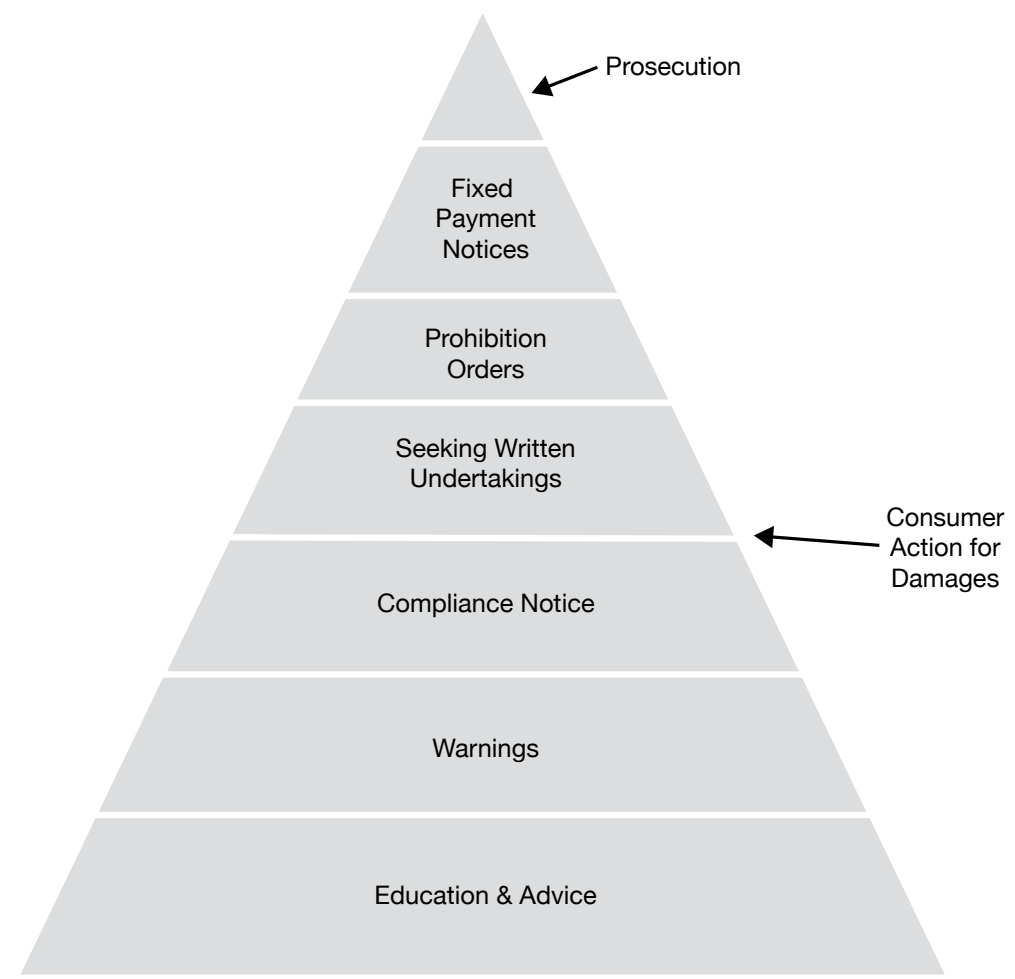

Figure 16.2 Enforcement pyramid under the Irish Consumer Protection Act 2007

Source: Adapted from Ayres and Braithwaite (1992). 
Governments have, increasingly, learnt this lesson and pay considerable attention to the array of levels of sanctions that may be invoked, building ever more responsive character into them-for example, by including voluntary commitments around compliance and consent to enforcement actions within the sanctions that may be deployed. An example is provided by the Consumer Protection Act 2007 in Ireland, which constitutes a wellstructured enforcement pyramid in which formal sanctions include the issue of compliance notices by the regulator, the securing of written undertakings to comply from the regulatees, prohibition orders and fixed payment notices before the top-level sanction of criminal prosecution is reached. There is, additionally, the possibility of consumers pursuing an action for damages (see Figure 16.2).

A key component of the pyramidal approach to enforcement is that it is responsive to its environment (Ayres and Braithwaite 1992: 4). While it is traditional to view regulatory enforcement as a bilateral process in which enforcement is imposed on regulatees by regulators, the responsive approach recognises that the characteristics and posture of the regulatee are also relevant to how enforcement actions will be received and acted on. Kagan and Scholz (1984), for example, have distinguished the political citizens (who are fundamentally committed to being compliant with their legal obligations), the amoral calculators (who comply only where this aligns with their financial interests) and the organisationally incompetent (who lack the capacity to comply even if they wish to). The pyramidal approach responds with the insight that the first group will generally comply with education and advice, the second will require credible threats of escalation to comply and the third group should be removed from the market with licence revocation or equivalent. More recent work has built on this sensitivity to the enforcement environment to argue for 'really responsive regulation' (Baldwin and Black 2008), which seeks to understand better the cognitive frameworks within which enforcement takes place (legitimate and illegitimate enforcement, for example), and the broader institutional environment (for example, which other actors may shape tendencies towards compliance-such as NGOs and consumers boycotting firms perceived as immoral) and, more generally, the limits of traditional regulatory tools.

Among lawyers, a central legitimacy concern with the model of responsive enforcement is that it argues for treating similar or identical transactions in different ways, apparently breaching a fundamental tenet of the rule of law concerned with generality of applications of laws (McDonald 2004; 
Westerman 2013). A further challenge to rule-of-law ideals arises from the opacity that may result from the exercise of broad discretion around enforcement decisions (Job et al. 2007: 94). Both these challenges can be addressed simultaneously by requiring regulators to publish details of their enforcement policies, practices and activities. It is in the interests of all involved that regulatory enforcement is predictable, as this promotes compliance for the regulator and creates a stable environment for regulatees.

The use of the insights around responsive regulation to make a more transparent and responsive enforcement structure is demonstrated by measures taken in the United Kingdom. In 1998, the UK Government adopted a soft law instrument called the Enforcement Concordat, in which signatory agencies in central and local governments agreed to follow a set of principles for regulatory enforcement that included consultation over standards, openness over enforcement policies and practices, helpfulness (for example, in assisting with compliance), the development of user-friendly complaints systems, proportionality and consistency (Department of Trade and Industry 1998). The concordat set down a partnership approach between regulators and businesses for securing regulatory compliance and was linked to the wider objectives of the government's 'Better Regulation' program, which was concerned with reducing the cost of regulation to businesses. The UK Government built on this approach with reviews of regulation generally (Hampton 2005) and enforcement in particular (Macrory 2006), which led to a more general and statutory application of responsive enforcement principles in the Regulatory Enforcement and Sanctions Act 2008 and the statutory Regulators' Compliance Code. In one view, these measures have made a responsive and cooperative approach to regulatory enforcement transparent and linked it to core principles of proportionality and consistency. For some, however, this approach represents the application of a neoliberal agenda and the degradation of regulatory enforcement because of the priority given to softer measures, even where more stringent enforcement would be merited (Tombs and Whyte 2013; cf. Braithwaite 2008: Chapter 1).

\section{Regulatory design}

It is clear from the discussion of the well-structured and broken pyramids that there is a significant element of design involved in creating an effective enforcement pyramid. A more obvious aspect of design is put 
forward in another section of Responsive Regulation. Alongside the enforcement pyramid, Ayres and Braithwaite also developed a pyramid of technique, which offers a theoretical prescription for regulatory design. It is this aspect of their book, Responsive Regulation, which perhaps most justifies the subtitle, Transcending the Deregulation Debate. The insights of this analysis underpin the now standard statements in regulatory design and better regulation discourse to the effect that with any policy problem for which regulation offers itself as a solution we should, first, consider the option of doing nothing, on the basis that any intervention may make matters worse and, second, consider the option of depending on or seeking some form of self-regulation. Only when these options have been considered and rejected should more intrusive regulatory techniques be proposed, involving, for example, civil penalties, criminal sanctions or licensing.

A central argument of the pyramid of technique is that governments should recognise the scope for delegating regulatory tasks to businesses and business associations but frequently with the oversight role of enforced self-regulation (Ayres and Braithwaite 1992: Chapter 4). From this important idea, originally put forward in 1982 (Braithwaite 1982), has come a stream of literature from Braithwaite, his colleagues-notably, Peter Grabosky and Christine Parker-and others, developing the idea of meta-regulation. In this perspective, a key role for the state lies in observing and steering self-regulatory capacity (Gilad 2010; Parker 2002; Parker and Braithwaite 2003). Rather than simply delegating, this involves the state in trusting more, but also verifying more, requiring considerable expertise and capacity (Gilad 2010).

Taken together, the pair of responsive regulation pyramids-the first on enforcement and the second on technique-has significantly enhanced the capacity for understanding and implementing some of the key tools of the regulatory state and, in particular, the promulgation and enforcement of rules. With enforcement, my own experience asking regulators about how they enforce their rules is that most describe something like the enforcement pyramid, many have been schooled in it and those who have not mostly recognise an outline pyramid and can discuss in articulate fashion the particular components of their own pyramid and how they relate to each other (see also Braithwaite 2011: 480; Mascini 2013; Parker 2013: 3-4). Many regulators have engaged directly with the enforcement 
pyramid and, increasingly, governments drawing up legislation have become cognisant of the importance of making available a range of gradated sanctions to avoid the risk of the broken pyramid.

The Australian Taxation Office (ATO), for example, worked directly with Val Braithwaite, John Braithwaite and colleagues in the Australian Centre for Tax System Integrity to redesign their enforcement practices in line with the responsive recipe of a two-way process of learning from which Val Braithwaite was able to learn more about the significance of motivational posture for designing enforcement techniques, while at the same time opening the ATO to learning about how to enhance compliance. Key aspects of the project were to engender cultural change in the ATO through training and reflection, enabling it to build and implement a responsive enforcement pyramid (Job et al. 2007: 90).

The Organisation for Economic Co-operation and Development (OECD) has embraced policies of regulatory reform and better regulation since the 1980s, drawing both implicitly and explicitly on the pyramid of regulatory design to suggest how states should address the challenge of regulatory responses to policy problems (OECD 2012). While the high-level recommendations of the OECD reflect Ayres and Braithwaite's policy prescription, the practice among states has been quite mixed and, arguably, whatever commitments have been made in theory have overwhelmingly rejected the proper implementation of the pyramid of technique approach. The European Commission (EC) appointed in 2014 recommitted itself to the development of better regulation strategies and made an explicit commitment to including well-designed self-regulation and co-regulation among the instruments to be deployed (EC 2015: 6).

There are, of course, exceptions. Perhaps the most developed is the pattern of private regulation of the advertising industry, which has swept Europe since the early 1960s. The advertising industry was concerned about its credibility following the sensational lifting of the lid on its techniques in a widely read book (Packard 1957). The UK industry responded with private regulation, which has been progressively enhanced, often with both encouragement and threats from government to legislate. The peak European organisation for private advertising regulation today represents effective private regulatory bodies across the EU and beyond, and has significant trust not only from national governments, but also from the European Commission (Verbruggen 2013). Similar stories might be told about press regulation in the United Kingdom and Ireland, where 
self-regulation has been a significant element of control in respect of press content, and governments have responded with threats and reform where the self-regulatory measures were found wanting (O'Dowd 2009).

More typically, however, European governments, and the EU legislature itself, have tended to make regulatory rules without proper evaluation of alternative techniques in terms of their capacity both for more effective outcomes or for reducing costs to regulatees (Brown and Scott 2011). The weakness in implementing the pyramidal approach to technique may be partly because the research base for the prescription has been less well developed. Relatedly, we do not know enough about what motivates governments to reach for rules to address policy problems rather than try other techniques that can harness the capacities and commitments of other actors. There is, of course, a significant concern that only the state is well equipped to deliver the public interest in public policy. Such concerns require a careful inquiry into the extent to which public and private interests are or can be aligned within a regulatory or metaregulatory context (Gunningham and Sinclair 2009).

So, the scorecard thus far suggests that the enforcement pyramid has been a highly successful policy idea; the pyramid of technique, less so. Why should this be? It may be that expert regulatory agencies are better able to respond to ideas and innovations whereas governments as a whole, in their legislative function, are, first, less expert and, second, overcome by political imperatives to adopt measures that indicate at least symbolic commitment to an aspiration to control matters. This may provide an explanation for other core ideas in responsive regulation, beyond the enforcement pyramid and technique pyramid, receiving an even poorer reception, with the consequence that much in responsive regulation theory that was most insightful about the relationship of the state to other key actors has been neglected (Mascini 2013).

\section{Regulatory capitalism beyond the state}

I have previously suggested in my own work that Braithwaite's work overemphasises the role of the state in contemporary regulatory governance (Scott 2004; see also Grabosky 2013). Having considered Braithwaite's response and his later work, I now believe I was wrong. While many and perhaps most of Braithwaite's readers took from his work chiefly to understand and to develop state regulation, it has 
been shown they, like me, have given the work only a partial reading. Rereading Responsive Regulation in light of the work that follows it suggests that the scholarly and policy readerships of the 1990s were more ready for what Braithwaite had to offer in terms of the development of the state's capacity for regulation and willing to neglect the other aspects of Braithwaite's work that show how he conceives of the role and relationships of all social actors, state, market and community in creating effective regulatory regimes. The introduction to the concept of responsive regulation in the 1992 volume focuses centrally on delegation of regulatory tasks to regulated businesses, to competitors and to interest groups (Ayres and Braithwaite 1992: 4), yet the primary influence of the book has been concerned with its prescriptions for state regulatory agencies. I have noted already that the pyramid of technique has been less influential particularly in its advocacy of greater use of self-regulation and enforced self-regulation. Other aspects of the book, which call for greater dependence on market and civil society actors within regulatory regimes, have been even less noted.

The central, neglected theme of Responsive Regulation concerns the potential for delegating regulation to others and embracing such delegated regulators within wider networks within which state authorities are liable to be key actors. We have noted already the importance of enforced self-regulation (and subsequently meta-regulation), in which the state oversees businesses and business associations in regulating themselves. A further technique offered by Ayres and Braithwaite, regulatory tripartism, involves drawing the commitments and resources of interest groups into regulatory roles. This analysis explicitly recognises that regulation of business is frequently not a bilateral game and that state, business and civil society actors within any policy setting are likely to be fragmented and diverse (Ayres and Braithwaite 1992: Chapter 3). The empowering of civil society actors such as interest groups draws in alternative capacity both for contributing to policymaking and for monitoring the actions and motivations of business actors pursuing self-interest and state actors at risk of capture. While acknowledging such risks, the analysis does not preclude the possibility of misbehaviour by interest groups. Thus, while some interest groups will be well aligned to the public policy objectives of measures with which they may be involved in enforcing, others may be captured by firms or may be overzealous in their tasks, irrationally pursuing symbolic rewards from enforcement activities that do not promote compliance (or cooperation) (Ayres and Braithwaite 1992: 74-7). The theoretical case for tripartism put forward 
by Ayres and Braithwaite is very strong, but, admittedly, not so well developed empirically. A second aspect of Responsive Regulation that has been neglected is the model of asymmetric regulation developed under the rubric of 'partial industry intervention', under which both firms and government learn from comparing the effects of regulation on market actors with the conduct of firms that are substantially unregulated (Ayres and Braithwaite 1992: Chapter 5). This model effectively delegates to the firms-regulated and unregulated-aspects of the application of regulation to the unregulated firms.

So, Responsive Regulation sets down core roles in building regulatory regimes for both community and market actors, but these aspects of the work have been little observed and acted on. Others have sought to extend the theory of responsive enforcement to directly address the fragmented character of contemporary regulatory governance. The elaboration of the three-sided enforcement pyramid attributes a role in enforcement not only to state agencies but also to civil society and market actors (Grabosky 1997). The idea of parallel enforcement capacity for other actors, using market power or private or public enforcement rights, offers the advantage of harnessing more wide-ranging monitoring and enforcement capacity, similar to Ayres and Braithwaite's concern to recognise the enforcement potential of public interest groups to reduce dependence on the diligence of public regulators. Indeed, Braithwaite himself, in a central passage of Regulatory Capitalism, has demonstrated the potential for 'networked escalation' to address weaknesses in enforcement capacity (Braithwaite 2008: 94-108). However, the recognition of this capacity also has the potential to be disruptive of responsive enforcement, since measured approaches by public regulators might be disrupted, as Ayres and Braithwaite acknowledge, by overzealous interest groups or others.

For the majority of readers in scholarly and policy communities, especially me, who failed to get the core themes of Responsive Regulation concerned with recognising and taking advantage of fragmentation in regulatory policy settings, Braithwaite's subsequent work offers increasingly insistent pointers. These works include a major statement on how a new theory of a separation of powers might envisage state, market and community actors holding each other in check through their overlapping capacities and interests (Braithwaite 1997). Braithwaite's work with Peter Drahos on global business regulation explores how standards with international reach are set through regulatory webs or networks of participants, each bringing different aspects of highly 
fragmented capacity (Braithwaite and Drahos 2000). Braithwaite's 2008 book, Regulatory Capitalism - titled following a term developed by Jacint Jordana (2005) and David Levi-Faur (2005) —is important not simply for the novelty of its ideas, but also, and perhaps more significantly, for its restatement of a position that could be found in the earlier work through a response to critics (Braithwaite 2008). We see clear indications of his interest in addressing the decentring of regulation (Black 2001) and of nodal governance (Burris et al. 2005), and the identification of the more limited role for the state in securing effective regulatory outcomes.

The fundamental problem within this decentred world is how to address key problems of ordering, not only for the state, but also for communities and markets. Within the EU, a novel approach to the regulatory challenges of the digital society has been to establish a community of practice concerned with self-regulation and co-regulation, drawing in governmental, market and community actors to deliberative processes that examine the relationship between governmental authority and selfregulatory capacity. A key objective for this group might be to rewrite the protocols on lawmaking in the EU to give recognition and legitimacy to appropriate self-regulatory and co-regulatory instruments (EC 2015).

\section{Conclusions}

The rise of the regulatory state has been a central trend in public policymaking within the OECD member states since the 1980s. While regulatory science has offered much to enhance the capacity of states to design and implement effective regulatory strategies, the advice to policymakers is as often ignored as it is implemented. Nevertheless, a core area of influence of John Braithwaite's work has been on enhancing public regulation, especially in the dimension of enforcement, where his fingerprints may be found on the numerous enforcement agencies around the world that use some version of the enforcement pyramid as a guide to action. The centrality of the state to discussions of how to address key public policy challenges has tended to obscure the importance of market and community actors in developing and implementing solutions to key ordering problems. As we consider how to enhance the capacity of the regulatory state, we should simultaneously give greater priority to techniques that draw in the capacity of others, and which locate the state as one of a number of key actors in making regulatory governance effective. John Braithwaite offers a vision of how we may enhance a 
more nuanced version of state regulatory capacity, oriented not only to recognising the limits of the state, but also to devising mechanisms for learning within implementation processes (Braithwaite 2011: 512-18) and a wider deliberative democratic experimentalism (Braithwaite 2008: 206-7). Such an approach takes us beyond state actors and draws in both market and community actors, and the range of mechanisms through which they may act, to achieve public interest objectives and more generalised wellbeing. These concerns are not limited to the industrialised countries (the traditional territory of the regulatory state), but apply equally and increasingly to the challenges arising from globalisation (Abbott and Snidal 2013) and the governance of developing countries (Braithwaite 2013; Braithwaite and Drahos 2000; Ford 2013), in each case demonstrating significant and often interrelated challenges for state capacity.

\section{Further reading}

Braithwaite, J 2011. 'The essence of responsive regulation', University of British Columbia Law Review 44: 475-520.

Dubash, NK and Morgan, B 2012. 'Understanding the rise of the regulatory state of the South', Regulation \& Governance 6: 261-81. doi.org/10.1111/j.1748-5991.2012.01146.x.

Grabosky, P 1994. 'Beyond the regulatory state', Australian and New Zealand Journal of Criminology 27: 192-7. doi. org/10.1177/000486589402700207.

Levi-Faur, D 2013. "The odyssey of the regulatory state: From a "thin" monomorphic concept to a "thick" and polymorphic concept', Law E Policy 35: 29-50. doi.org/10.1111/lapo.12000.

Parker, C 2013. 'Twenty years of responsive regulation: An appreciation and appraisal', Regulation E Governance 7: 2-13. doi.org/10.1111/ rego.12006. 


\section{References}

Abbott, KW and Snidal, D 2013. 'Taking responsive regulation international: Strategies for international organizations', Regulation $\mathcal{E}^{\circ}$ Governance 7: 95-113. doi.org/10.1111/j.1748-5991.2012.01167.x.

Ayres, I and Braithwaite, J 1992. Responsive Regulation: Transcending the Deregulation Debate. Oxford: Oxford University Press.

Baldwin, R and Black, J 2008. 'Really responsive regulation', Modern Law Review 71(1): 59-94. doi.org/10.1111/j.1468-2230.2008.00681.x.

Barron,A and Scott,C 1992.'The citizen's charter programme', The Modern Law Review 55(4): 526-46. doi.org/10.1111/j.1468-2230.1992. tb00930.x.

Black, D 1976. The Behavior of Law. New York: Academic Press.

Black, J 2001. 'Decentring regulation: The role of regulation and selfregulation in a "post-regulatory" world', Current Legal Problems 54(1): 103-46. doi.org/10.1093/clp/54.1.103 .

Braithwaite, J 1982. 'Enforced self-regulation: A new strategy for corporate crime control', Michigan Law Review 80: 1466-507. doi. org/10.2307/1288556.

Braithwaite,J 1997.'On speaking softly and carrying big sticks: Neglected dimensions of a republican separation of powers', University of Toronto Law Journal 47: 305-61. doi.org/10.2307/825973.

Braithwaite, J 2000. 'The new regulatory state and the transformation of criminology', British Journal of Criminology 40: 222-38. doi. org/10.1093/bjc/40.2.222.

Braithwaite, J 2008. Regulatory capitalism: How it works, ideas for making it work better. Cheltenham, UK: Edward Elgar. doi. org/10.4337/9781848441262.

Braithwaite, J 2011. 'The essence of responsive regulation', University of British Columbia Law Review 44: 475-520.

Braithwaite, J 2013. 'Relational republican regulation', Regulation E Governance 7: 124-44. doi.org/10.1111/rego.12004. 
Braithwaite, J and Drahos, P 2000. Global Business Regulation. Cambridge: Cambridge University Press.

Brown, C and Scott, C 2011. 'Regulation, public law and better regulation', European Public Law 17: 467-84.

Burris, S, Drahos, P and Shearing, C 2005. 'Nodal governance', Australian Journal of Legal Philosophy 30: 30-58.

Collins, H 1999. Regulating Contracts. Oxford: Oxford University Press.

Cranston, R 1979. Regulating Business: Law and Consumer Agencies. London: Macmillan. doi.org/10.1007/978-1-349-03849-7.

Crawford, A 2006. 'Networked governance and the post-regulatory state? Steering, rowing and anchoring the provision of policing and security', Theoretical Criminology 10: 449-79. doi. org/10.1177/1362480606068874.

Department of Trade and Industry 1998. Enforcement Concordat: Good Practice Guide for England \& Wales. London: Department of Trade and Industry.

Esping-Andersen, G 1990. The Three Worlds of Welfare Capitalism. Cambridge: Polity Press.

European Commission (EC) 2015. Better regulation for better results: An EU agenda, Communication from the Commission to the European Parliament, the Council and the European Economic and Social Committee and the Committee of the Regions, European Commission, Brussels. Available at: ec.europa.eu/smart-regulation/ better_regulation/documents/com_2015_215_en.pdf.

Ford, C 2013. 'Prospects for scalability: Relationships and uncertainty in responsive regulation', Regulation \& Governance 7(1): 14-29. doi. org/10.1111/j.1748-5991.2012.01166.x.

Gilad, S 2010. 'It runs in the family: Meta-regulation and its siblings', Regulation E Governance 4(4): 485-506. doi.org/10.1111/j.17485991.2010.01090.x.

Grabosky, P 1997. 'Inside the pyramid: Towards a conceptual framework for the analysis of regulatory systems', International Journal of the Sociology of Law 25: 195-201. doi.org/10.1006/ijsl.1997.0040. 
Grabosky, P 2013. 'Beyond Responsive Regulation: The expanding role of non-state actors in the regulatory process', Regulation E' Governance 7(1): 114-23. doi.org/10.1111/j.1748-5991.2012.01147.x.

Grabosky, P and Braithwaite, J 1986. Of Manners Gentle: Enforcement Strategies of Australian Business Regulatory Agencies. Melbourne: Oxford University Press.

Gunningham, N and Sinclair, D 2009. 'Organizational trust and the limits of management based regulation', Law and Society Review 43: 865-900. doi.org/10.1111/j.1540-5893.2009.00391.x.

Hampton, P 2005. Reducing Administrative Burdens: Effective Inspection and Enforcement. London: HM Treasury.

Harding, R 1997. Private Prisons and Public Accountability. New Brunswick, NJ: Transaction Publishers.

Hood, C, Scott, C, James, O, Jones, G and Travers, T 1999. Regulation Inside Government: Waste-Watchers, Quality Police, and Sleaze-Busters. Oxford: Oxford University Press. doi.org/10.1093/0198280998.001 .0001 .

Job, J, Stout, A and Smith, R 2007. 'Culture change in three taxation administrations: From command-and-control to responsive regulation', Law E Policy 29: 84-101. doi.org/10.1111/j.14679930.2007.00247.x.

Jordana, J 2005. 'Globalizing regulatory capitalism', The Annals of the American Academy of Political and Social Science 598: 184-90. doi. org/10.1177/0002716204272780.

Kagan, R and Scholz, J 1984. "The "criminology of the corporation" and regulatory enforcement strategies', in K Hawkins and J Thomas (eds), Enforcing Regulation. Boston: Kluwer-Nijhoff, pp. 67-95. doi. org/10.1007/978-94-017-5297-8_4.

Levi-Faur, D 2005. 'The global diffusion of regulatory capitalism', The Annals of the American Academy of Political and Social Science 598: 12-32. doi.org/10.1177/0002716204272371.

Levi-Faur, D 2013. 'The odyssey of the regulatory state: From a "thin" monomorphic concept to a "thick" and polymorphic concept', Law E Policy 35: 29-50. doi.org/10.1111/lapo.12000. 
Levi-Faur, D 2014. 'The welfare state: A regulatory perspective', Public Administration 92: 599-614. doi.org/10.1111/padm.12063.

Loader, I 2000. 'Plural policing and democratic governance', Social and Legal Studies 9: 323-45. doi.org/10.1177/096466390000900301.

Loughlin, M and Scott, C 1997. 'The regulatory state', in P Dunleavy, I Holliday, A Gamble and G Peele (eds), Developments in British Politics. Book 5. Basingstoke, UK: Macmillan, pp. 205-19. doi. org/10.1007/978-1-349-25862-8_10.

Mabbett, D 2011. 'The regulatory rescue of the welfare state', in D LeviFaur (ed.), Handbook on the Politics of Regulation. Cheltenham, UK: Edward Elgar, pp. 215-26. doi.org/10.4337/9780857936110.00027.

McDonald, L 2004. "The rule of law in the "new regulatory state", Common Law World Review 33(3): 197-221. doi.org/10.1350/ clwr.33.3.197.36498.

Macrory, R 2006. Regulatory Justice: Making Sanctions Effective. London: Cabinet Office.

Majone, G 1994a. 'Paradoxes of privatization and deregulation', Journal of European Public Policy 1(1): 53-69. doi. org/10.1080/13501769408406947.

Majone, G1994b. 'The rise of the regulatory state in Europe', West European Politics 17(3): 77-101. doi.org/10.1080/01402389408425031.

Mascini, P 2013. 'Why was the enforcement pyramid so influential and what was the price paid', Regulation E Governance 7(1): 48-60. doi. org/10.1111/rego.12003.

Moran, M 2003. The British Regulatory State: High Modernism and Hyper-Innovation. Oxford: Oxford University Press. doi.org/10.109 3/0199247579.001.0001.

O’Dowd, J 2009. 'Ireland's new defamation act', Journal of Media Law 1: 173-90.

Organisation for Economic Co-operation and Development (OECD) 2012. Recommendation of the Council on Regulatory Policy and Governance. Paris: OECD. Available at: oecd.org/governance/ regulatory-policy/2012-recommendation.htm. 
Packard, V 1957. The Hidden Persuaders. New York: David McKay.

Parker, C 2002. The Open Corporation: Self-Regulation and Democracy. Melbourne: Cambridge University Press. doi.org/10.1017/ CBO9780511550034.

Parker, C 2013. 'Twenty years of responsive regulation: An appreciation and appraisal', Regulation E Governance 7: 2-13. doi.org/10.1111/ rego.12006.

Parker, C and Braithwaite, J 2003. 'Regulation', in P Cane and M Tushnet (eds), The Oxford Handbook of Legal Studies. Oxford: Oxford University Press, pp. 119-45.

Prosser, T 1997. Law and the Regulators. Oxford: Oxford University Press.

Schultz, R and Doern, B 1998. 'No longer "governments in miniature": Canadian sectoral regulatory institutions', in B Doern and S Wilks (eds), Changing Regulatory Institutions in Britain and North America. Toronto: University of Toronto Press, pp. 108-30. doi. org/10.3138/9781442679184-006.

Scott, C 2002. 'Private regulation of the public sector: A neglected facet of contemporary governance', Journal of Law and Society 29: 56-76. doi.org/10.1111/1467-6478.00211.

Scott, C 2004. 'Regulation in the age of governance: The rise of the post-regulatory state', in J Jordana and D Levi-Faur (eds), The Politics of Regulation. Cheltenham, UK: Edward Elgar, pp. 145-74. doi.org/1 $0.4337 / 9781845420673.00016$.

Scott, C 2010. 'Regulatory crime: History, functions, problems, solutions', in U Kilkelly and S Kilcommins (eds), Regulatory Crime in Ireland. Dublin: First Law, pp. 63-86.

Selznick, P 1985. 'Focusing organizational research on regulation', in R Noll (ed.), Regulatory Policy and the Social Sciences. Berkeley: University of California Press, pp. 363-8.

Thatcher, M 2007. Internationalisation and Economic Institutions: Comparing European Experiences. Oxford: Oxford University Press. doi.org/10.1093/acprof:oso/9780199245680.001.0001. 
Tombs, S and Whyte, D 2013. 'Transcending the deregulation debate? Regulation, risk and the enforcement of health and safety law in the UK', Regulation E Governance 7: 61-79. doi.org/10.1111/j.17485991.2012.01164.x.

Verbruggen, P 2013. 'Gorillas in the closet: Public and private actors in the enforcement of transnational private regulation', Regulation E Governance 7: 512-32. doi.org/10.1111/rego.12026.

Westerman, P 2013. 'Pyramids and the value of generality', Regulation E Governance 7: 80-94. doi.org/10.1111/j.1748-5991.2012.01155.x.

White, A 2014. 'Post-crisis policing and public-private partnerships', British Journal of Criminology 54: 1002-22. doi.org/10.1093/bjc/ azu063. 
This text is taken from Regulatory Theory: Foundations and applications, edited by Peter Drahos, published 2017 by ANU Press, The Australian National University, Canberra, Australia. 